\title{
A report on species of phyllidiid and polycerid nudibranch including two species new to Korea
}

\author{
Daewui Jung ${ }^{1}$, Jongrak Lee ${ }^{2}$ and Chang-Bae Kim ${ }^{1, *}$ \\ ${ }^{1}$ Department of Green Life Science, Sangmyung University, Seoul 110-743, Korea \\ ${ }^{2}$ Marine Biodiversity Research Institute, INTHESEA KOREA Inc., Jeju 697-110, Korea \\ *Correspondent: evodevo@smu.ac.kr
}

\begin{abstract}
During a systematic study on Korean nudibranchs, two phyllidiid and two polycerid species were collected and identified with examination of their external morphological characters. As a result of the study, two phyllidiid species, Phyllidia ocellata Cuvier, 1804 and Phyllidiella pustulosa (Cuvier, 1804) were redescribed since there was no descriptions of these species with Korean specimens. And two polycerid species, Thecacera pennigera (Montagu, 1815) and Triopha catalinae (Cooper, 1863) were described as new to Korean fauna. Diagnostic characters of these species are described with illustrations in this study. DNA barcode data from three species examined were also provided for a supplement to morphological identifications.
\end{abstract}

Keywords: Korea, Nudibranchia, Phyllidia ocellata, Phyllidiella pustulosa, Phyllidiidae, Polyceridae, Thecacera pennigera, Triopha catalinae

\section{INTRODUCTION}

Nudibranchs comprising more than 6,000 species worldwide are distinguished by missing a shell in the adult stage. Species included in the family Phyllidiidae having no primary gill and comprising hard tubercles in dorsal part of body can be easily separated from the species of related families (Gosliner et al., 2008). Within the family, species are distinguished by characteristic color variation of body and spacing of the dorsal tubercles. The family Polyceridae is distinguished by having velar tentacles along anterior part of body, and extrabranchial and lateral appendages (Gosliner et al., 2008).

Until now 8 species in families Phyllidiidae and Polyceridae have been recorded from Korean waters (Choe and Lee, 1997; Lee and Min, 2002; Choi, 2003): Phyllidia ocellata Cuvier, 1804; Phyllidia picta Pruvot-Fol, 1957; Phyllidiella cooraburrama Brunckhorst, 1993; Phyllidiella pustulosa (Cuvier, 1804) in the family Phyllidiidae; Plocamopherus tilesii Bergh, 1877; Tambja amakusana Baba, 1987; Tambja sagamiana (Baba, 1955); Tambja verconis (Basedow and Hedley, 1905) in the family Polyceridae. There was no taxonomic report with descriptions on species included in these families from Korean waters.
In this study, we reported brief re-descriptions with figures of two species in the family Phyllidiidae, Phyllidia ocellata Cuvier, 1804 and Phyllidiella pustulosa (Cuvier, 1804) and two species in the Polyceridae, Thecacera pennigera (Montagu, 1815) and Triopha catalinae (Cooper, 1863 ) as new to Korea with presentation of diagnoses and illustrations. In addition, mitochondrial COI DNA sequence data of three species examined were presented for an aid of species identification.

\section{Materials And Methods}

Materials were collected by scuba diving in the subtidal zone of the Korean coast from June 2011 to October 2012. The collected specimens were narcotized with a $10 \% \mathrm{MgCl}_{2}$ solution, and fixed in $10 \%$ neutral buffered formalin or $97 \%$ ethanol to preserve. The specimens were examined with a stereoscopic microscope (Olympus SZ61 with FuzhouTucsen TCA-3). Body lengths of most specimens were measured from the middle points of the rhinophores to the tip of posterior end by using ocular micrometers. Examined specimens were deposited at the National Institute of Biological Resources (NIBR), Incheon, Korea and Sangmyung University, Seoul, Korea. NIBR specimen numbers are recorded for the specimens. 
For molecular identification, genomic DNA was extracted from isolated tissues. Mitochondrial COI gene was amplified (500 bp) using a universal primer set (LCO1490, HCO2198; Former et al., 1994). PCR products were purified and analyzed by DNA sequencing. Each of the primers was removed and open reading frame was obtained as sequences translated into protein to avoid numts. GenBank reference sequences have been searched to the resulting sequences using BLAST.

\section{Systematic Accounts}

Phylum Mollusca Linnaeus, 1758

Class Gastropoda Cuvier, 1817

Order Nudibranchia Cuvier, 1817

Family Phyllidiidae Rafinesque, 1814

Diagnosis. Elongate-ovate shape. Retractable lamellate rhinophores. Primary gill absent. Secondary gill flat and trianglular in shape. Mantle skirt covers the foot. Tough body and generally possessed hard dorsal tubercles. Radula or jaws absent (Brunckhorst, 1993).

Genus Phyllidia Cuvier, 1797

\section{Phyllidia ocellata Cuvier, 1804 (Fig. 1)}

Phyllidia ocellata Cuvier, 1804: 269, pl. a, fig. 7 (cited from Yonow, 1996). Brunckhorst, 1993: 35-37, figs 25D-E, pls. 2D-H, 3A; Yonow, 1996: 485-487, fig. 1, tab. 1; Choe and Lee, 1997: 38, tab. 1; Okutani, 2000: 795, fig. 3; Lee and Min, 2002: 145; Choi, 2003: 47, pl. 5; Debelius and Kuiter, 2007: 265; Gosliner et al., 2008: 287.

Phyllidiopsis carinata Eliot, 1910: 435-436, pl. 25, figs. 8, 9, 12 (cited from Yonow, 1996).

Phyllidia multituberculata Boettger, 1918: 129-130, pl. 8, fig. 4a-c (cited from Brunckhorst, 1993); Yonow, 1996: 487-490, figs. 2A-E, 3A-G, 4B, tab. 1.

Phyllidia tuberculata Baba, 1930: 117-118, pl. 4, fig. 1a-d (non Phyllidia tuberculata Risbec, 1928) (cited from Brunckhorst, 1993).

Phylldia japonica Baba, 1937: 310 (cited from Brunckhorst, 1993); Baba, 1949:72, 157, pl. 29, fig. 108; Lim and Chou, 1970: 134, pl. 16c (cited from Yonow, 1996).

Phylldia baccata Pruvot-Fol, 1957: 111-113, figs. 1321, pl. 1b (cited from Brunckhorst, 1993).

Phyllidia ocellata undula Yonow, 1986: 1411-1413, figs. 5, 12a, b (cited from Brunckhorst, 1993).

Material examined. 1 individual, Jeju-do, Seogwipo-si, Seogwi-dong. 19 Feb 2012; 1 individual (KOSPIV0000 164403), Jeju-do, Seogwipo-si, Seogwi-dong. 13 Oct
2013; 1 individual, Jeju-do, Seogwipo-si, Seogwi-dong. 14 Oct 2013.

Diagnosis. Body ovate and elongate (length: 42-63 mm, width: 26-40 mm). Rhinophores lamellate and dark yellow in color (Fig. 1A). Anus open with yellow border. Anus papilla white (Fig. 1B). Back ground color brightly yellow. Dorsum several various sizes of patches of black rings bordered with white, rounded or conical tubercles scattered. Median dorsal tubercles appear to line up longitudinally. Tubercles usually decrease in size from top to edge of mantle (Fig. 1C). Sole of foot gray, divided anteriorly (Fig. 1D). Oral tentacles finger like in shape, rounded ends (Fig. 1E).

Distribution. Korea, Southern Japan, Thailand, Philippines, Indo-west Pacific, Indonesia, Australia, South Africa, Tanzania, Madagascar, Mauritius, Seychelles, Red Sea to Maldives, Fiji, Solomon Island, Papua New Guinea,Vanatu, Gaum to Marshall Island.

DNA barcode. COI sequences of the first mentioned specimen in the "Material examined" are as follows: 5'CGATCATTTTTATAATGTTATTGTAACAGCTCA TGCTTTTGTAATAATTTTCTTTTTGGTAATACCT TTAATAATTGGGGGGTTCGGAAATTGAATGGTC CCATTACTAATTGGTGCTCCAGACATAAGATTT CCCCGAATAAATAATATAAGTTTTTGGTTACTA CCACCATCTTTTATTTTATTATTATGCTCAACTTT AATAGAAGGTGGAGCTGGAACAGGGTGAACTG TTTATCCCCCATTATCTGGACCAATAGGACATG GTGGGACTTCTGTTGATTTAGTAATTTTTTCTTT ACACTTAGCTGGAGCCTCTTCTCTTCTAGGGGC AATTAATTTTATTACTACTATCTTCAATATACGT TCACCTGCTATAACAATGGAACGTTTAAGATTA TTTGTTTGGTCAGTTTTAGTGACAGCTTTTCTTT TACTTCTTTCTTTACCTGTTTTAGCAGGGGCTAT TACTATACTTTTAACGGATCGAAATTTTAACA-3'.

According to BLAST search to GenBank, this sequence matches $88 \%$ with Phyllidia elegans (AJ223276). There is no COI sequence information for $P$. ocellata in the GenBank. Therefore more COI records from different localities of the species are needed for correct molecular identification.

Remarks. Phyllidia ocellata is known as variety of color pattern, even from a single locality (Gosliner et al., 2008). In Korea, however, all of specimens examined in this study and previous study (Choi, 2003) are shown same dorsal patterns with bright yellow background and 7-8 black thick rings and several patches.

Genus Phyllidiella Bergh, 1869

\section{Phyllidiella pustulosa (Cuvier, 1804) (Fig. 2)}

Phyllidia pustulosa Cuvier, 1804: 268, pl. a, fig. 8 (cited from Brunckhorst, 1993); Baba, 1949: 18, 71, 156, pl. 29. 

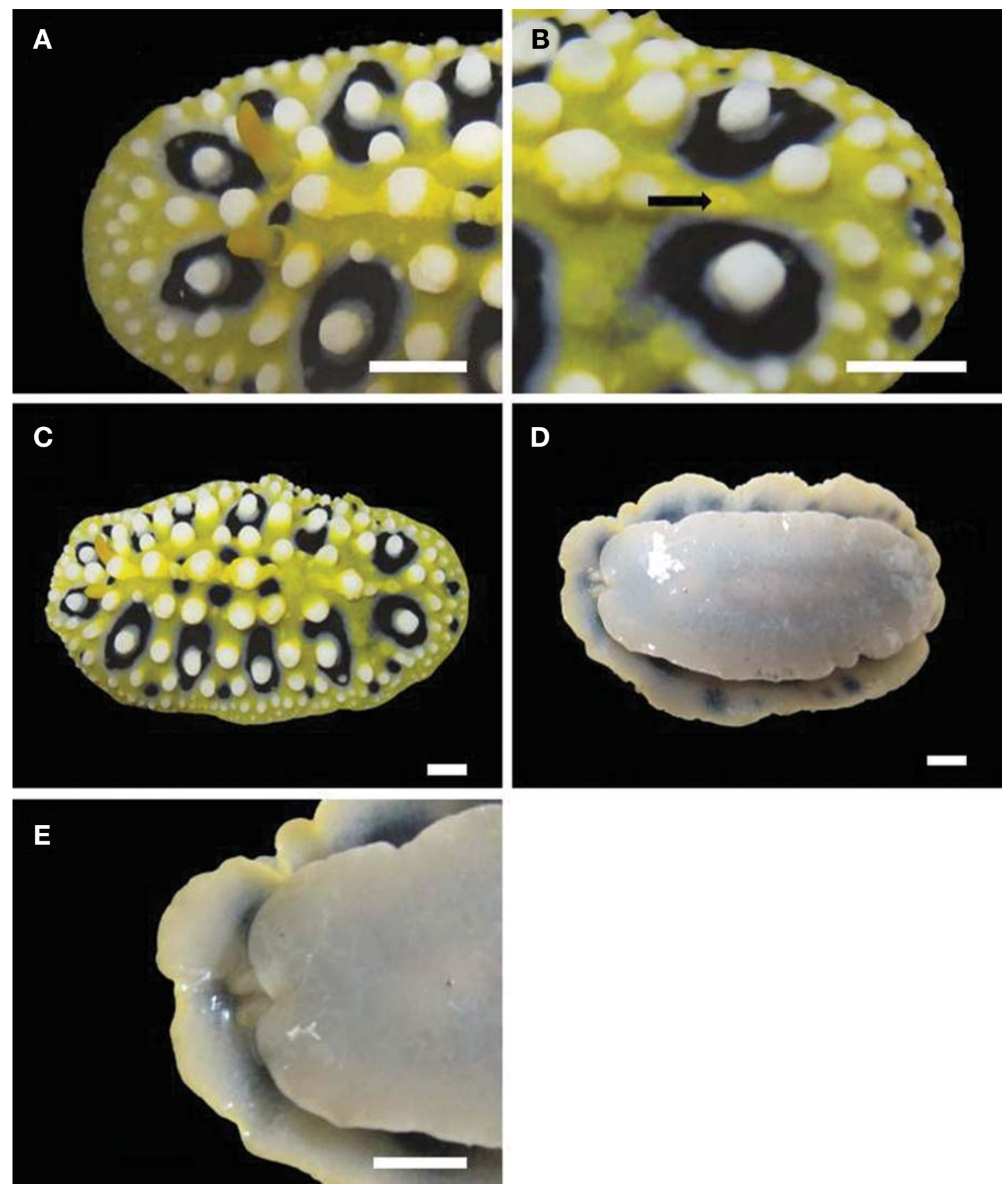

Fig. 1. Pyllidia ocellata Cuvier, 1804. A. rhinophores. B. anus. C. dorsal view. D. ventral view. E. oral tentacles. A-C. living animal. D, E. preserved specimen. An arrow indicates anus. Scales $=5 \mathrm{~mm}$.

Phyllidia verrucosa Hasselt, 1824: 244 (cited from Brunckhorst, 1993).

Phyllidia albonigra Quoy and Gaimard, 1832: 291-292, pl. 21, figs. 26, 27 (cited from Brunckhorst, 1993).

Phyllidiella nobilis Bergh, 1869: 485-492, 512-513, pl. 24b (cited from Brunckhorst, 1993).

Phyllidia spectabilis Collingwood, 1881: 136-137, pl. 10, figs. 19-23 (cited from Brunckhorst, 1993).

Fryeria variabilis Collingwood, 1881: 137, pl. 10, figs. 24-28 (cited from Brunckhorst, 1993).

Phyllidia rotunda Eliot, 1904: 282-283 (cited from Brunckhorst, 1993).

Fryeria pustulosa: Haas, 1920: 140 (cited from Brunckhorst, 1993). 

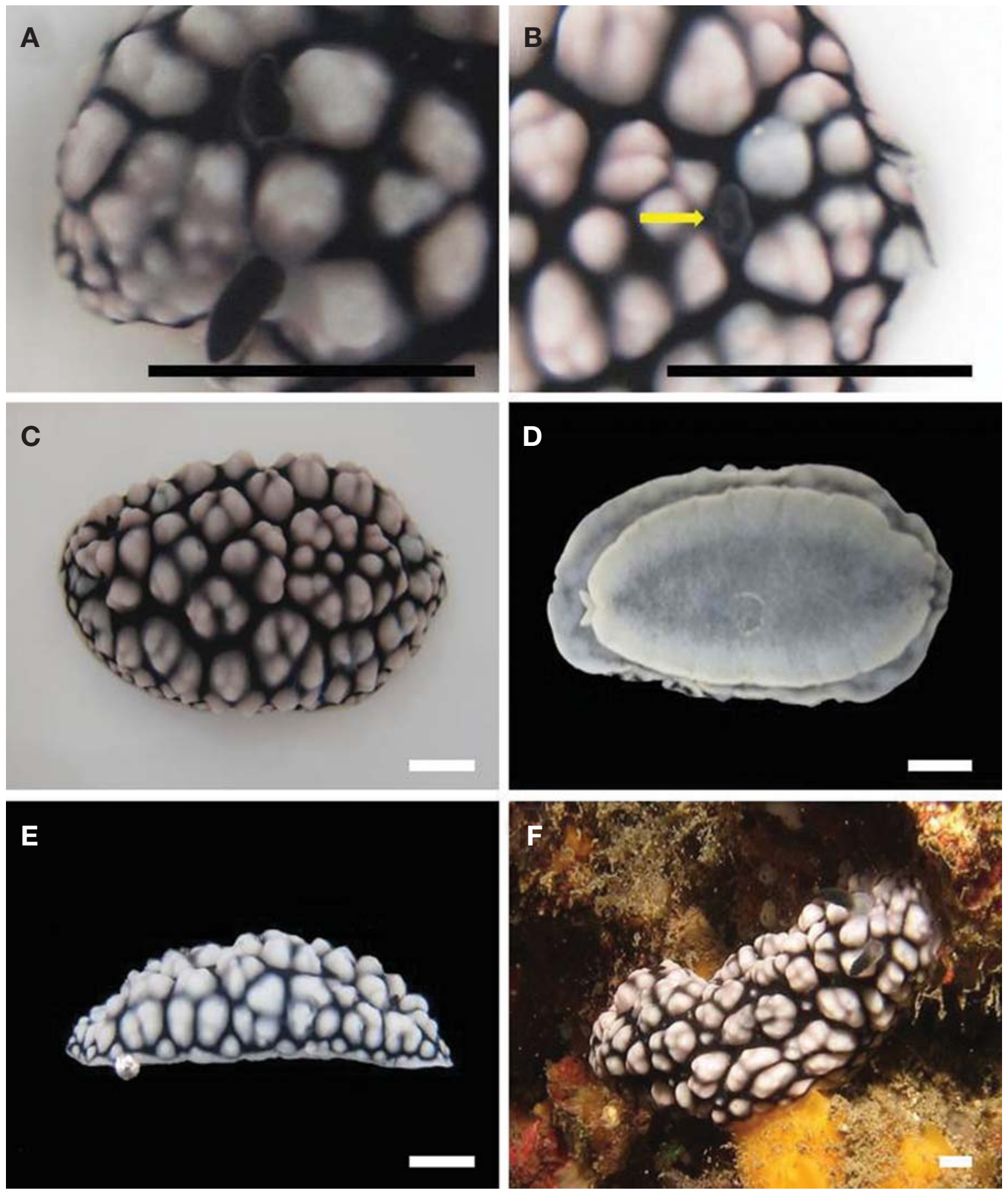

Fig. 2. Phyllidiella pustulosa (Cuvier, 1804). A. rhinophores. B. anus. C. dorsal view. D. ventral view. E. lateral view. F. habitus. An arrow indicates anus. A-E. preserved specimen. F. living animal. Scales $=5 \mathrm{~mm}$.

Phyllidia nobilis: Risbec, 1928: 58 (cited from Brunckhorst, 1993).

Phyllidia variabilis: Risbec, 1956: 24 (cited from Brunckhorst, 1993).

Phyllidia varians Pruvot-Fol, 1956: 68 (mis-spelling pro. Fryeria variabilis Collingwood, 1881) (cited from Brunckhorst, 1993).
Phyllidia melanocera Yonow, 1986: 1406-1407, figs. 2, 10f-i (cited from Brunckhorst, 1993).

Phyllidiella pustulosa: Brunckhorst, 1993: 49-54, figs. 3B, 9B-D, 11-13, 27, 28A-C. pl. 5E-F; Choe et al., 1997: 39, figs. 4-5, tab. 3; Okutani, 2000: 795, fig. 2; Valdés, 2001: 339, figs. 1B, 5B-C, 6; Lee and Min, 2002: 145; Choi, 2003: 52, pl. 6; Debelius and Kuiter, 
2007: 269; Gosliner et al., 2008: 293.

Material examined. 1 individual (SMD0178), Jeju-do, Seogwipo-si, Seogwi-dong. 19 Feb 2012; 1 individual (KOSPIV0000164403), Jeju-do, Seogwipo-si, Seogwidong. 13 Oct 2013.

Diagnosis. Body ovate and elongate (length: $30-53 \mathrm{~mm}$, width: $26-31 \mathrm{~mm}$ ). Rhinophores lamellate and black in color (Fig. 2A). Anus open with black border (Fig. 2B). Back ground color black. Pinkish gray tubercles clustered 2-3 protuberances with variable in shape and size on dorsum (Fig. 2C, F). Sole of foot gray, divided anteriorly. Oral tentacles finger like in shape (Fig. 2D). Edge of mantle submarginal black line (Fig. 2E).

Distribution. Korea, Japan, Indo-west Pacific to Hawaii, New Caledonia, Fiji.

Family Polyceridae Alder and Hancock, 1845

Diagnosis. Varied body shape. Usually velar tentacles along anterior margin. Dorsal extrabranchial appendages and other lateral appendages (Gosliner et al., 2008).

Genus Thecacera Fleming, 1828

\section{Thecacera pennigera (Montagu, 1815) (Fig. 3)}

Doris pennigera Montagu, 1815: 17-18, pl. 4, fig. 5 (cited from Vallés et al., 2000).

Thecacera pennigera: Fleming, 1828: 283 (cited from Willan, 1976); Alder and Hancock, 1855, fam. 1, pl. 21a, figs. 1-9 (cited from Baba, 1960); Willan, 1976: 347-352, fig. 1; Vallés et al., 2000: 26, figs. 7C, 9; Debelius and Kuiter, 2007: 40.

Thecacera maculata Eliot, 1905: 241-243 (cited from Vallés et al., 2000).

Thecacera pennigera var. nigrescens Labbé, 1931: 20 (cited from Willan, 1976).

Thecacera lamellate Barnard, 1933: 294-295, fig. 1 (cited from Vallés et al., 2000).

Material examined. 1 individual, Gangwon-do, Goseonggun, Jugwang-myeon, Munamjin-ri. 18 Aug 2012; 2 individuals (KOSPIV0000157372), Gyeongsangbuk-do, Uljin-gun, Wonnam-myeon, Doeksin-ri. 29 Aug 2012.

Diagnosis. Body slender (length: 13-17 mm, width: 9-12 $\mathrm{mm})$ with translucent white. Blunte head. Pointed metapodium (Fig. 3A). Dorsum convex and high (Fig. 3B). Rhinophores lamellate with incomplete sheath. Rhinophores surrounded by bifurcate rhinophoral sheath (Fig. 3C). Gills five bipinnate on center of dorsum. Two very long elongated extrabranchial appendages on both sides of gills (Fig. 3D). Numerous yellow and black spots scattered (Fig. 3E, F).

Distribution. Korea, Japan, Parkistan, France, England,
Netherlands, Atlantic-USA, South Africa, Angola, Brazil, Australia, New Zealand.

DNA barcode. COI sequences of the first mentioned specimen in the "Material examined" are as follows: 5'GTGCCTTTTTAGGGGACGATCATTTTTATAATG TTATTGTTACTGCACATGCCTTTGTTATAATTTT TTTCATAGTTATACCAGTAACTATAGGAGGTTT CGGAAATTGAATAATTCCTTTATTAATTGGAGC TCCGGATATGAGTTTTCCTCGAATAAACAACAT AAGATTCTGATTTTTACCTCCTTCATTTGTTTTA CTTTTATGTTCTACTCTCATGGAAGGGGGTGCTG GAACAGGTTGAACTGTTTACCCTCCTTTGTCTG GACCTGTAGGCCATAGGGGTGCTTCTGTGGATC TTGCTATTTTCTCTTTACATCTAGCAGGTGCTTC ATCATTATTGGCTTCAATTAACTTTATTACTACT ATTCTTAATATACGGTCTTCAGCAATAAGTTTC GAGCGGGTGAGGTTGTTTGTATGGTCTCTTTTA GTGACAGCATTCCTTTTACTTCTTTCGTTACCGG TATTAGCAGGTGCTATTACTATATTACTGACA-3'.

According to BLAST search to GenBank, this sequence matches $86 \%$ with a COI record of Thecacera pennigera (AJ223277; reported from Spain), single COI record from this species in the GenBank. But, the similarity value shown between two records was not significant indication that two COI records were derived from the same species even though the identification of the species was correct. This means that this species is composed of at least two separate species. Therefore, to prove it more COI records are needed from diverse known localities.

Remarks. Thecacera pennigera is widely distributed worldwide. Willan (1976) suggested that the species spread beyond its original distributional range of distribution by transportation by ship. By examination of present specimens, there was no discrete morphological difference between present specimens and those from other countries except size and number of spots on mantle.

Genus Triopha Bergh, 1880

Triopha catalinae (Cooper, 1863) (Fig. 4)

Triopa catalinae Cooper, 1863: 59.

Triopa carpenteri Stearns, 1873: 78, fig. 2 (cited from McDonald, 1983).

Triopha carpenteri: Bergh, 1880: 112-117 (cited from McDonald, 1983); MacFarland, 1966: 106, pls. 19, 29, 31; Okutani, 2000: 779, fig. 2.

Triopha modesta Bergh, 1880: 261-266, pl. 14, figs. 1720 (cited from McDonald, 1983).

Triopa modesta: Fischer, 1887: 527 (cited from McDonald, 1983).

Triopha catalinae: Cockerell, 1915: 229 (cited from McDonald, 1983); Ferreira, 1977: 388-396, figs. 1-11, 16; McDonald, 1983: 215; Goddard, 1984: 153; Debelius 

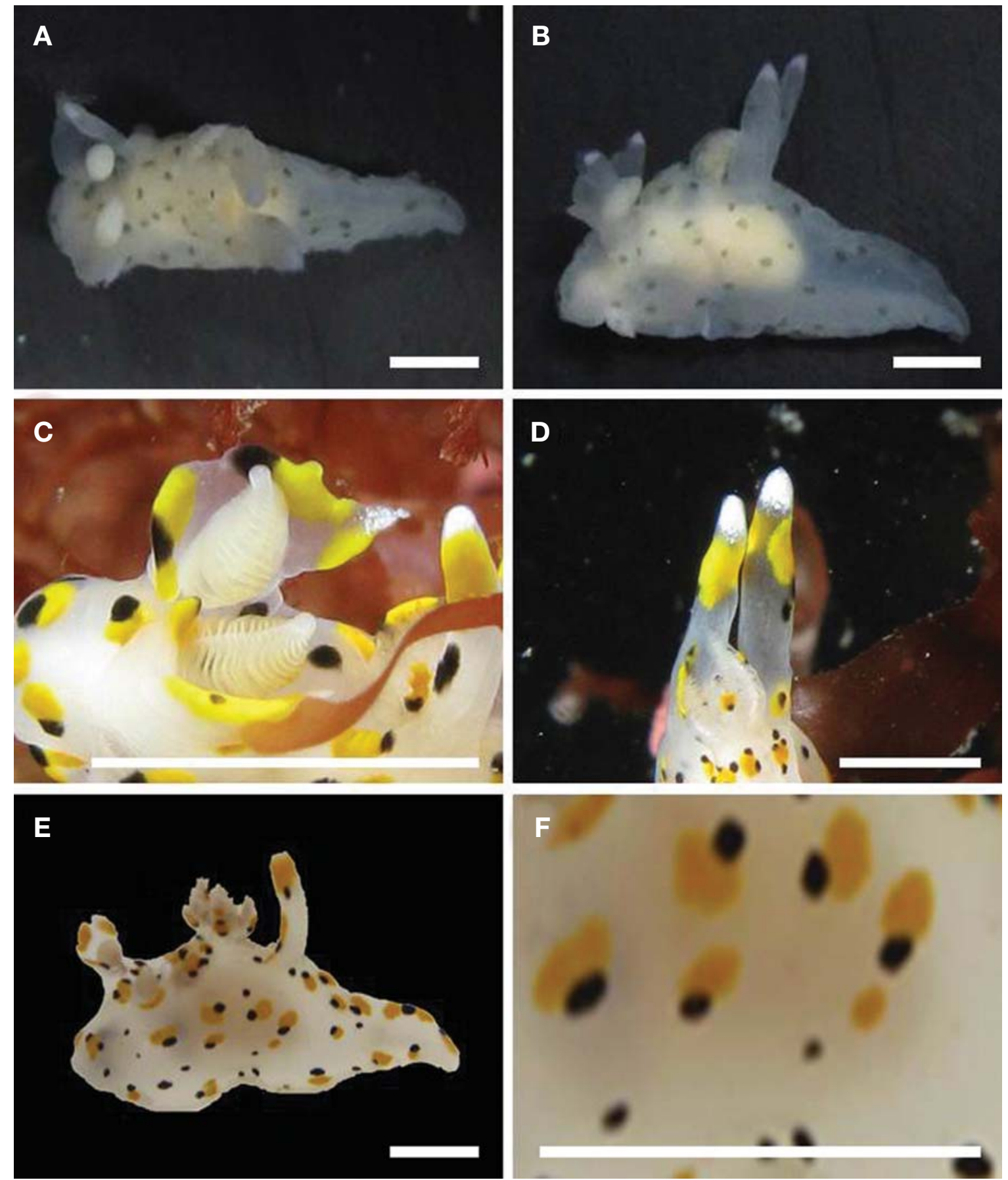

Fig. 3. Thecacera pennigera (Montagu, 1815). A. dorsal view. B. lateral view. C. rhinophores and rhinophoral sheath. D. gills and extrabranchia appendages. E. habitus, living animal. F. pattern of spots. A, B. preserved specimen. C-F. living animal. Scales=1 mm.

and Kuiter, 2007: 46; Gosliner et al., 2008: 277.

Triopha scrippsiana Cockerell, 1915: 228-229 (cited from McDonald, 1983).

Triopha elioti O’Donoghue, 1921: 165-167 (cited from McDonald, 1983).

Material examined. 1 individual, Gangwon-do, Goseonggun, Toseong-myeon, Bongpo-ri, 28 May 2012; 3 indivi- duals, Gangwon-do, Yangyang-gun, Hyeonbuk-myeon, Gisamun-ri, 6 Jun 2012; 3 individuals (KOSPIV000016 5265), Gangwon-do, Goseong-gun, Jugwang-myeon, Munamjin-ri, 18 Aug 2012.

Diagnosis. Body elongate (length: 46-100 mm, width: 15-38 $\mathrm{mm}$ ) and translucent pale white, Anterior rounded, Posterior pointed (Fig. 4A). Head flattened and expand- 

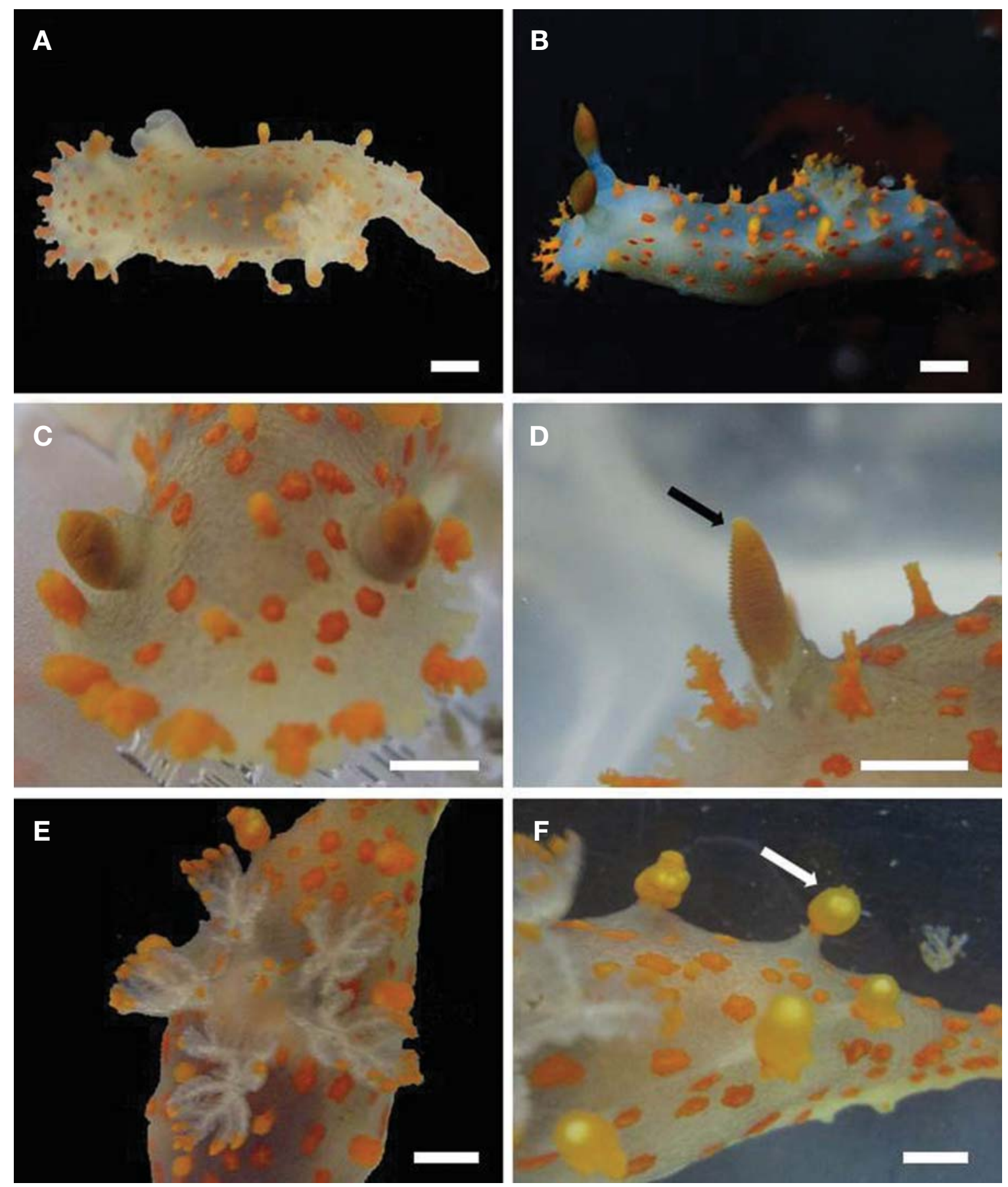

Fig. 4. Triopha catalinae (Cooper, 1863). A. dorsal view. B. lateral view. C. head. D. rhinophore. E. gills. F. tubercles. A-F. living animal. Scales $=5 \mathrm{~mm}$.

ed wider than body (Fig. 4B). Several margin process of frontal veil along anterior of head (Fig. 4C). Rhinophores lamellate and retractable (Fig. 4D). Gills five of simple tripinnate and non-retractable (Fig. 4E). Dorsum slightly arched, Usually several rounded end tubercles on edge of dorsum (Fig. 4E). Same orange color present tip of appendage: Rhionophores, Dorsal-lateral papillae, Dorsal tubercles, Frontal veil margin process, Gill branch, Posterior end.

Distribution. Korea, Japan, Alaska, Baja California, Mexico.

DNA barcode. COI sequences of the first mentioned specimen in the "Material examined" are as follows: 5'AGCTGGTGCATTTCTAGGGGATGATCATTTTTA 
TAATGTCATTGTAACTGCTCATGCGTTCGTAAT AATTTTTTTTATAGTTATGCCGTTAATAATCGGA GGATTTGGTAACTGAATAGTTCCTTTACTAATT GGAGCACCTGATATAAGTTTTCCTCGAATAAAT AATATAAGATTTTGACTTCTTCCCCCCTCATTTA TTTTATTGTTGTGTTCAACATTAATAGAAGGAG GAGCTGGGACAGGATGAACTGTGTACCCTCCTT TATCTGGTCCTGTGGGTCATGGAGGTACGTCTG TAGATCTTGCTATTTTTTCTCTCCATTTAGCTGG CGCATCTTCTTTACTTGGGGCCATTAATTTTATT ACTACTATTTTTAATATACGCTCTTCGGCTATAA CTATAGAACGATTAAGTTTATTCGTTTGGTCTGT TTTGGTGACTGCTTTTCTACTCTTGCTTTCTTTA CCTGTACTAGCCGGAGCTATTACTATACTAT-3'.

According to BLAST search to GenBank, this sequence matches $99 \%$ with a COI record of Triopha catalinae (GQ292040) available in the GenBank. This may support the morphological identification of the species.

Remarks. Triopha catalinae distributed from Alaska to Baja California in the Eastern Pacific. From the Western Pacific Okutani (2000) recorded this species from Sanri$\mathrm{ku}$ and Hokkaido. The present report of $T$. catalinae from Korea showed a distributional extension of its previously known range.

\section{ACKNOWLedGements}

This study was financially supported by a grant from the Discovery of Korean Indigenous Species Project provided by National Institute of Biological Resources (NIBR), Korea. We also thank Hyunju Kang, Team Deep Abyss and Jiyeon Lee, Jijeong Middle School for providing photographs.

\section{REFERENCES}

Baba, K. 1949. Opishobranchia of Sagami bay. Iwanami shoten, Tokyo. pp. 1-194.

Baba, K. 1960. The genera Polycera, Palio, Greilada and Thecacera from Japan (Nudibranchia-Polyceridae). Publications of the Seto Marine Biological Laboratory 8(1):7578.

Bouchet, P. and J.P. Rocroi. 2005. Classification and nomenclator of gastropod families. Malacologia 47(1-2):1-397.

Brunckhorst, D.J. 1993. The systematics and phylogeny of phyllidiid nudibranchs (Doridoidea). Records of the Australian Museum supplement 16:1-107.

Choe, B.L. and J. Lee. 1997. Unrecorded phyllidiid nudibranchs from Cheju Island waters in Korea with remarks on new locality data and intraspecific color variations. Korean Journal of Malacology 13(1):37-42.

Choi, M. 2003. Classification of Doridacea (Gastropoda, Nu- dibranchia) from sea shores around Je-ju Island. MS thesis, Sungkyunkwan University, Kyonggi-do, Korea. pp. $1-69$.

Cooper, J.G. 1863. On new or rare Mollusca inhabiting the coast of California. Proceedings of the California Academy of Sciences 3:56-60.

Debelius, H. and R.H. Kuiter. 2007. Nudibranchs of the world. IKAN-Unterwasserarchiv, Frankfurt. pp. 1-360.

Ferreira, A.J. 1977. A review of the Genus Triopha (Mollusca: Nudibranchia). Veliger 19(4):387-402.

Folmer, O., M. Black, W. Hoeh, R. Lutz and R. Vrijenhoek. 1994. DNA primers for amplification of mitochondrial cytochrome $\mathrm{c}$ oxidase subunit I from diverse metazoan invertebrates. Molecular Marine Biology and Biotechnology 3:294-299.

Goddard, J.H.R. 1984. The opisthobranchs of Cape Arago, Oregon, with notes on their biology and a summary of benthic opisthobranchs known from Oregon. Veliger 27 (2):143-163.

Gosliner, T.M., D.W. Behrens and Á. Valdés. 2008. IndoPacific nudibranchs and sea slugs. A field guide to the world's most diverse fauna. Sea Challengers Natural History Books and California Academy of Sciences, Gig Harbor, Washington. pp. 1-426.

Lee, J.S. and D.K. Min. 2002. A catalogue of molluscan fauna in Korea. Korean Journal of Malacology 18(2):93-217.

MacFaland, F.M. 1966. Studies of opisthobranchiate mollusks of the Pacific coast of North America. Memoirs of the California Academy of Sciences vol. 6, San Francisco. pp. 1-546.

McDonald, G.R. 1983. A review of the nudibranchs of the California coast. Malacologia 24(1-2):114-276.

McDonald, G.R. 2009. Nudibranch systematic index, 2nd ed. Institute of Marine Sciences, UC Santa Cruz, Santa Cruz. pp. 1-723.

Okutani, T. 2000. Marine mollusks in Japan. University of Tokyo Press, Tokyo. pp. 1-1173.

Valdés, Á. 2001. Deep-water phyllidiid nudibranchs (Gastropda: Phyllidiidae) from the tropical south-west Pacific Ocean. In: P. Bouchet \& B.A. Marshall (eds.), Tropical Deep-sea Benthos, volume 22. Mémoires du Muséum national d'histoire naturelle 185:331-368.

Vallés, Y., Á. Valdés and J. Ortea. 2000. On the phanerobranch dorids of Angola (Mollusca, Nudibranchia): a crossroads of temperate and tropical species. Zoosystema 22 (1):15-31.

Willan, R.C. 1976. The opisthobranch Thecacera pennigera (Montagu) in New Zealand, with a discussion of the genus. Veliger 18(4):347-352.

Yonow, N. 1996. Systematic revision of the Family Phyllidiidae in the Indian ocean province: part 1 (Opisthobranchia: Nudibranchia: Doridoidea). Journal of Conchology 35(6): 483-516.

Submitted: December 31, 2012, Accepted: February 5, 2013 